\title{
透析に伴ら後天性腎囊胞に発生した腎細胞癌の免疫学的検討
}

\begin{tabular}{ccccc} 
& & \multicolumn{2}{c}{ 東京慈恵会医科大学泌尿器科学教室 } & \\
大西 & 哲郎 & 町田 豊平 & 増田富士男 & 鳥居伸一郎 \\
白川 & 浩 & 波多野孝史 & 牧野 秀樹 &
\end{tabular}

\section{IMMUNOLOGICAL STUDY ON RENAL CELL CARCINOMA IN DIALYSIS PATIENTS WITH ACQUIRED CYSTIC DISEASE OF KIDNEYS}

\author{
Tetsuro Onishi, Toyohei Machida, Fujio Masuda, Shinichiro Torii, Hiroshi Shirakawa, \\ Takashi Hatano and Hideki Makino \\ Department of Urology, Jikei University School of Medicine \\ (Director: Prof. T. Machida)
}

The immunological study of the major histocompatibility complex (class I, class II and DR antigens), tumour infiltrating lymphocytes (TIL), regional lymph node lymphocytes (RLNL) and peripheral blood lymphocytes (PBL) was evaluated on the basis of immunohistochemical staining using monoclonal antibodies of each subset of lymphocytes in a series of 16 patients with renal cell carcinoma. Two renal cell carcinomas in dialysis patients with acquired cystic disease of the kidneys (ACDK) were also included in this study. With regard to the immunological environment, a comparative study between renal cell carcinoma accompanied with ACDK and 14 other renal cell carcinoma was carried out.

The results are described below:

1) With regard to the expression of $\mathrm{MHC}$ antigens in tumour cells, the degrees of expression of MHC class I, class II and DR-antigen in case 1 were higher than that of the other 14 renal cell carcinomas. On the other hand, no expression of MHC was detected in case 2.

2) As to the subsets of TIL, the CD25 (IL-2 receptor) was not expressed in all the renal cell carcinoma. As to the T cell receptor (TCR-alpha/beta chain), the degree of expression was the same in case 1 and the other 14 cases. On the other hand, no TCR was detected in the case 2. As to the other subsets of TIL (CD3, CD4, CD8, CD16 and CD20), the rates of the infiltration were the same in case 1 and the other 14 cases, but those in case 2 were lesser than in all other 14 cases.

3) As to the subsets of RLNL, CD25 was not expressed in all the renal cell carcinomas. The degrees of expression of the TCR-alpha/beta chains were the same in case 1 and the other 14 cases, but not in case 2 . As to the other subsets, there observed an elevation of the CD3 (especially CD4) in case 1 compared with the other 14 cases. However, as to case 2 , all subsets were reduced compared with case 1 and the other 14 cases.

4) As to the subsets of PBL, the same ratio of each subset was observed in case 1 and the other cases. As to case 2, CD3 (especially CD4) was elevated compared with case 1 and the other 14 cases.

We conclude that there are severely immuno-suppressive cases like case 2 in the renal cell carcinoma patients with ACDK caused by dialysis.

Key words: renal cell carcinoma, acquired cystic disease of the kidneys, immunological study

要旨：免疫組織学的検討を行った腎細胞癌16例中, 透析腎に併発した後天性腎囊胞（ACDK）に発生し た腎細胞癌 2 例（症例 1 及び症例 2 ）の免疫的環境を検討し, 以下の結論を得た。

1）腫瘍細胞の MHC 発現は, 症例 1 では class I, class II 及び DR 抗原のいずれも, 対照症例に比較

して発現率は高かったが, 症例 2 ではいずれの MHC 発現も認められなかった.

2）腫瘍浸潤リンパ球（TIL）に抢けるCD25（IL-2 receptor）の表出は全ての症例で表出率が低かっ 
たが，T 細胞受容体（TCR）-alpha/beta chain は症例 1 では対照群と汪ぼ同程度の表出率であったが，

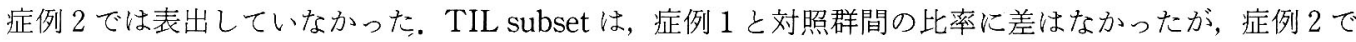
はいずれの subsetについても比率が低かった。

3）所属リンパ節リンパ球（RLNL）のCD25は全ての症例で表出がなく, TCR-alpha/beta chainの 比率は症例 1 と対照症例間に差はなかったが, 症例 2 は表出していなかった. RLNL subset は, 症例 1 は対照症例に比較して CD3陽性 T 細胞（その内の特に CD4陽性 T 細胞）の比率が高かったが，症例 2 では全ての subset 率が低かった。

4）末梢血リンパ球の subset では, 症例 1 と対照症例間に差はなかったが, 症例 2 では症例 1 及び対照 症例に比較して, CD3陽性 T 細胞の増加と，その内特に CD4陽性 T 細胞の比率が高かった。

従って, ACDK に発生した腎細胞癌には症例 2 の様なきわめて免疫学的応答の低い症例が存在するこ とが示唆された。

キーワード：腎細胞癌, 後天性腎囊胞, 免疫的検討

\section{緒 言}

血液透析の進歩により，慢性腎不全患者の長期生存 が可能となってきているが，一方，長期透析に伴って これまで明らかにされていなかった新しい病態がこれ ら患者に生じることが報告されつつある ${ }^{1221}$ ，その中 で，最近注目されている，腎の後天的囊胞化に伴う腎 の癌化がある ${ }^{3)}$. この問題は臨床的に患者の予後にか かわる重要な変化であるばかりか, 腎細胞癌や囊胞発 生の原因を解く重要な手がかりとなると考兄られる。

今回，透析患者に生じるこれら病態の一因として考 兊られている免疫的抑制状態に注目して検討を進め た.

\section{対象症例及び方法}

慈恵医大泌尿器科で1990年 6 月より 1991年 5 月京で の 1 年間に治療した腎細胞癌の内, 腫瘍組織を中心に 免疫的検索を行った症例は16例である。これら症例の 内, 腎不全による透析中に生じた後天性腎囊胞 (acquired cystic disease of the kidneys : 以下 ACDK と略す）に合併した腎細胞癌 2 症例を検討対象とし, その他の14例を比較対照症例とした。

1）対象症例の臨床及び病理的所見
対象 2 症例の罹患年齢は46.5歳（中央値）で，いず れの症例も男子で，かつ左側例であった。腎不全に至 る基礎疾患はいずれも慢性系球体腎炎で，透析法は血 液透析の久の例と，腹膜透析を合わせて施行した症例 であり，透析期間は 8 年から 14 年であった(Table 1). stageは, いずれも low stage(stage 1，2)で, grade

Fig. 1 症例 1 の組織像. 細胞型は, granular cell type. 組織構築は papillary pattern, 組織学的悪性 度は grade II であった（H \& E 染色, $\times 100)$.

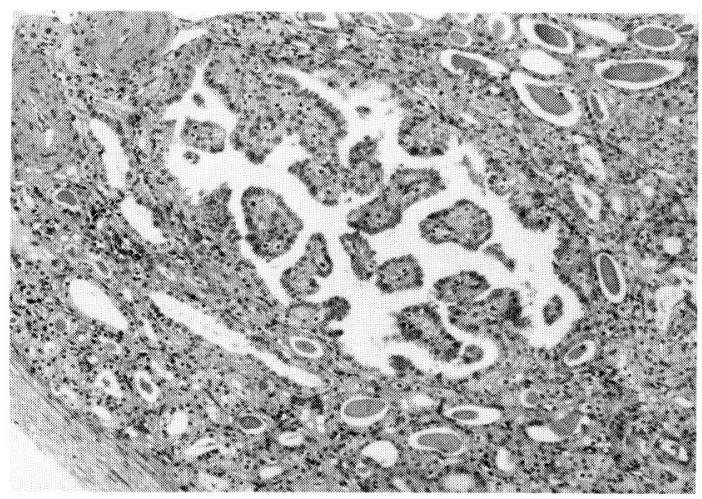

Table 1 対象症例の臨床的所見

\begin{tabular}{|c|c|c|c|c|c|c|c|c|c|c|c|}
\hline & 年齢 & 性 & 患側 & 基礎疾患 & 透析 & $\begin{array}{l}\text { 法及び } \\
\text { 析期間 }\end{array}$ & stage & grade & $\begin{array}{l}\text { cell } \\
\text { type }\end{array}$ & $\begin{array}{l}\text { 組瀻 } \\
\text { 築 }\end{array}$ & $\begin{array}{l}\text { daughter } \\
\text { tumour 数 }\end{array}$ \\
\hline $\begin{array}{l}\text { 症例 } 1 \\
\text { H. S.) }\end{array}$ & 48 & M & $\mathrm{L}$ & $\begin{array}{l}\text { 慢 性 } \\
\text { 舀球炎 }\end{array}$ & $\begin{array}{l}\text { 血液 } \\
\text { 透析 }\end{array}$ & 計14年間 & $\left(\begin{array}{c}{ }^{2} \\
\text { pNO, } 3, \mathrm{pO},\end{array}\right)$ & II & granular & papillary & 3 筬所 \\
\hline $\begin{array}{c}\text { 症例 } 2 \\
\text { (H. C. })\end{array}$ & 45 & $\mathrm{M}$ & L & $\begin{array}{l}\text { 慢 性 } \\
\text { 临球炎 }\end{array}$ & $\begin{array}{l}\text { 血液 } \\
\text { 透析 } \\
\text { 腹膜 } \\
\text { 透析 }\end{array}$ & $\begin{array}{r}3 \text { 年間 } \\
5 \text { 年間 } \\
\text { 計 } 8 \text { 年間 }\end{array}$ & $\left(\begin{array}{c}{ }^{1} \mathrm{~T} 2 \mathrm{~b}, \mathrm{pVO} \\
\mathrm{pNO}, \mathrm{MO}\end{array}\right)$ & I & clear & alveolar & 7 箇所 \\
\hline
\end{tabular}


についても low grade (grade I，II）であった。 また， 細胞型は症例 1 が granular cell type (Fig. 1), 症例 2 が clear cell type (Fig. 2) であり, 組織構築は, 症例 1 が papillary pattern (Fig. 1) で, 症例 2 が alveolar pattern (Fig. 2) であり，いずれの症例も腎 内に daughter tumor が 3 から 7 箇所認められ (Table 1)，その他，露胞壁には散在性に hyperplastic epithelium が認められた（Fig. 3).

2) 免疫組織染色法, 検討項目及び解析法

腎摘時得られた腎細胞癌を $3 \mathrm{~cm}$ 角に細切の後, OCT コンパウンド内で急速に凍結したものを検討材料とし た. 免度組織染色法は Table 2 に示した, 組織酵素抗 体法間接法を用いた。得られた標本を，各 subsetごと

Fig. 2 症例 2 の組織像. 細胞型は, clear cell type, 組織構築は alveolar pattern, 組織学的悪性度は grade I であった（H \& E 染色, $\times 100)$.

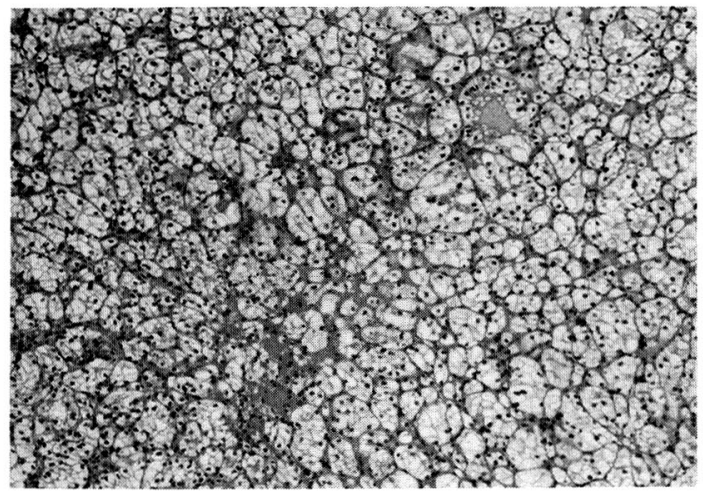

に写真撮影し，画像解析装置（Nexus 6000）を用い以 下の方法に従って陽性細胞比率を求めた。

a）腫瘍細胞上に発現した主要組織適合性抗原 (major histocompatibility complex : 以下 MHC と 略寸)比率：陽性細胞面積一CD3陽性細胞面積/全腫瘍 細胞面積

b) 腫瘍浸潤リンパ球 (tumuor infiltrating lymphocyte：以下 TIL と略す）及び所属リンパ節リ ンパ球 (regional lymph node lymphocyte: 以下 RLNL と略す) 比率：陽性細胞面積/有核細胞面積 (た だし， T 細胞受容体（T cell receptor：以下 TCR と 略す)に関しては：陽性細胞面積/CD3 陽性細胞面積） また，末梢血リンパ球(以下 PBL と略す)の subset

Fig. 3 症例 1 及び症例 2 に共通して散在性に豪胞壁 に認められた hyplastic epithelium の像（H＆E染 色, $\times 200)$.

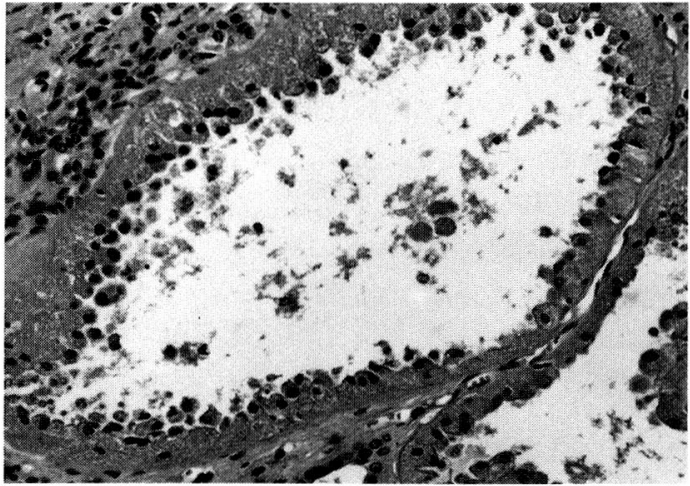

Table 2 免疫染色法

Step 1 (凍結包埋)：アルブミンを塗布したスライドグラスにクオイオスタットに より4〜 6u の厚さに薄切した凍結標本を乗せる。

Step 2 (切片固定, 洗浄)：30分間室温で風乾後, 冷アセトンで 5 分間固定の後, 冷 PSB で 5 分間ずつ 3 回洗浄.

Step 3 (非特異的反応防止処理)：切片を $10 \%$ 未感作血清（正常羊血清）で20分間 室温で処理, 軽く PBS で洗浄.

Step 4 (一次抗体反応)：第一抗体（monoclonal antibody）を毛細管ピペットで 切片に乗せ, 温室 (moisture chamber) の中で $37^{\circ} \mathrm{C}, 1$ 時間反応.

Step 5 (洗浄)：冷 PBS で 5 分間ずつ 5 回以上洗浄。

Step 6 (酵素標識抗マウス抗体反応)：HRP (horseradish peroxidase) 標識第二 次抗体と $37^{\circ} \mathrm{C}, 1$ 時間湿室中で反応。

Step 7 (洗浄)：冷 PBS で 5 分間ずっ 5 回以上洗浄.

Step 8 (DAB 発色): DAB- $\mathrm{H}_{2} \mathrm{O}_{2}$ 溶液 (3, $3^{\prime}$-diaminobenzidine) に $10 \mathrm{mM} ア シ$ 化 ナトリウムを加えたもので 5 分間, 室温で反応。

Step 9 (洗浄): 冷 PBS で 5 分間ずっ 3 回洗浄の後, 蒸留水で 2 回洗浄.

Step 10 (核染)：4\%×チールグリーン溶液で 1 時間後染色。

Step 11 (脱水, 封入): エタノール脱水, キシロール透徹の後, 封入, 検鏡. 
は，末梢血から得られた細胞の大きさによってサイト グラムを求め, リンパ球の細胞群を targeting した後, 各リンパ球の subsetに対するモノクローナル抗体と の反応を, 蛍光物質の強度によるヒストグラムとして flow-cytometryにて計測した。

今回使用したモノクローナル抗体は, MHC の class I (clone: W6•32(1), Lot No. ; 040), class II (clone : TAL. 1B5, Lot No. ; 087), DR 抗原 (clone: L243, Lot No; N0412, LO205) (いずれも DAKOPPATS 社 製）に加之て， $\mathrm{T}$ 細胞受容体（以下 TCR と略す）の alpha/beta chain (clone : 8A3, Lot No. ; 2265, 516) 及び gamma/delta chain (clone : 5A6. E9, Lot No. ; 2279，1512）（いずれも T CELL SCIENCES 社製）で ある.さらに, TIL の subset として CD3(pan T-cell : clone: SK7, Lot No. ; 0668), CD4 (helper/inducer T-cell ; clone: SK3, Lot No.; NO140, N1113), CD8 (cytotoxic/suppressor T-cell ; clone : SK1, Lot No. ; NO434, H1 216), CD16(NK-cell ; clone : G022, Lot No. ; M0144, LO401)(いずれも Becton-Dickinson 社製), さらに CD20(B-cell ; clone: H299, Lot No. ; $68 \mathrm{M} 144)$ (Coulter 社製), CD25 (interleukin-2 receptor：以下 IL-2 receptor と略す, clone: ACT-1, Lot No. ; 199) (DAKOPATTS 社製)である. 同様のモ) クローナル抗体を用いて，RLNLについても検討し た.

また stage 分類は Robsonの方式4)に準じ, grade 分 類は 4 段階法占を用いて検討した.

\section{結 果}

1) 腫瘍細胞の MHC 発現率比較 (Fig. 4)

症例 1 では対照群に比較して, MHC class I, II 及 び DR 抗原のいずれについても発現率が高かったが,

Fig. 4 腫煬細胞の MHC 抗原の発現に関する比較.

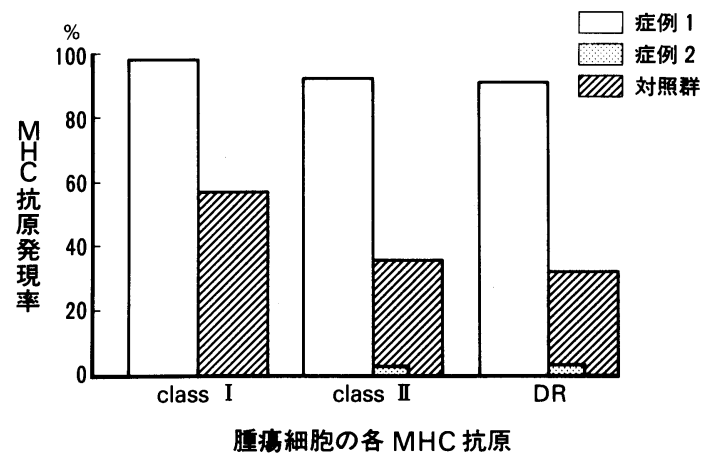

症例 2 ではいずれの抗原発現も極めて低かった。

2) TIL 中の CD25及び TCR の表出率比較 (Fig. 5) CD25については症例 1 , 症例 2 及び対照症例のいず れについても表出率はきわめて悪かった. TCR alpha/beta chain は症例 1 と対照症例はほぼ同率で 表出していたが, 症例 2 では表出しておらず，また， TCR-gamma/delta chain の表出率は全体として低い 結果であった。

3) TIL 中の subset 比率比較 (Fig. 6)

症例 1 については対照症例とほぼ同程度の各 subset 比率であったが, 症例 2 については全ての subset に関してその表出が低い結果であった。

4）RLNL 中の CD25及び TCR の表出率比較（Fig. 7)

CD25についてはいずれの症例も，また対照症例につ いてもその表出がみられなかった. TCR-alpha/beta chain は症例 1 及び対照症例はほぼ同率で表出してい たのに比較して症例 2 では表出されていなかった。 た TCR-gamma/delta は全ての症例でほとんど表出

Fig. 5 腫揚浸潤リンパ球の内, CD25(IL-2 receptor) 及び $\mathrm{T}$ 細胞受容体 (TCR) 表出率に関する比較.

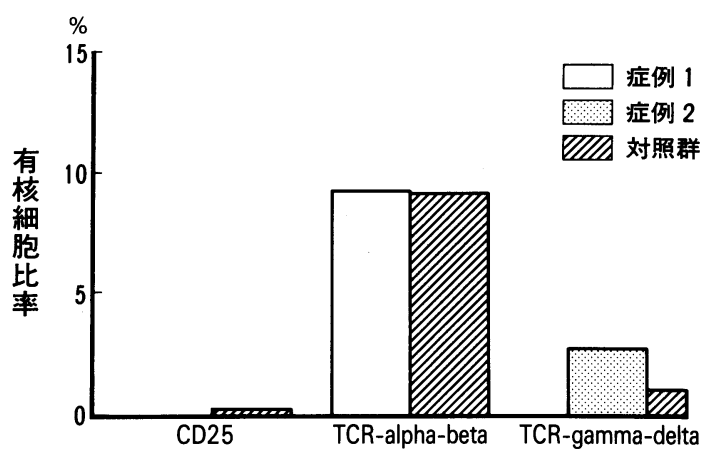

Fig. 6 腫瘍浸潤リンパ球の内, subset 比率比較.

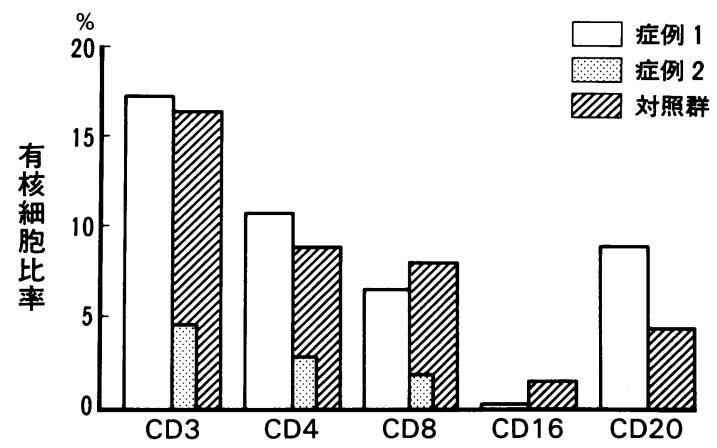


Fig. 7 所属リンパ節リンパ球の内, CD25(IL-2 receptor) 及び $\mathrm{T}$ 細胞受容体 (TCR) 表出率に関する比 較.

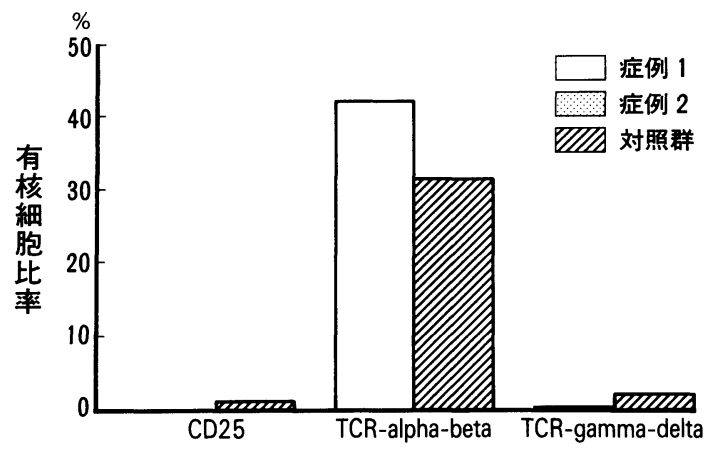

Fig. 8 所属リンパ節リンパ球の subset 比率比較.

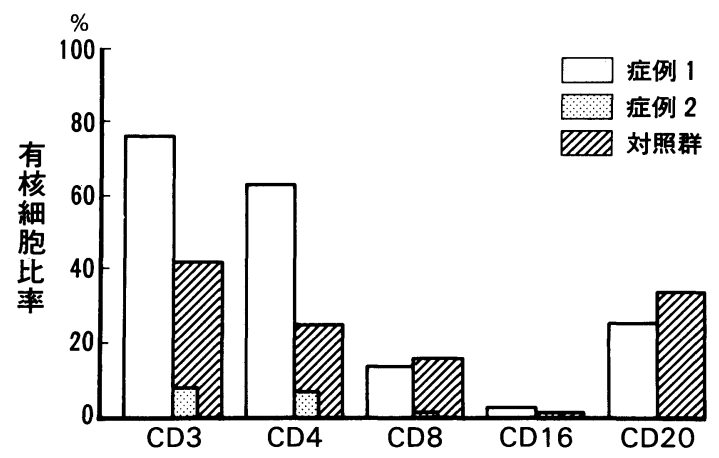

されていなかった。

5) RLNL 中の subset 比率比較 (Fig. 8)

症例 1 については, CD3, CD4は対照症例に比較して その表出率がむしろ高く, その他の subset はほぼ同率 であったが, 症例 2 は全ての subset でその表出率がき わめて低い結果であった。

6) PBL 中の subset 比率比較 (Fig. 9)

症例 1 と対照症例では全ての subset 比率について ほぼ同様の表出率が観察されたのに比較して, 症例 2 では対照症例及び症例 1 に比較して CD3及び CD4は やや表出率が高く, CD8及び CD16は逆に表出率が低 く，CD20は同定度の表出率であった。

長期透析患者の腎に囊胞性病変が生じることに関し て最初の報告を Dunnill ら ${ }^{6 /}$ が1977年行っている。それ によると, 透析患者30例の剖検結果, 14例に囊胞性変 化が認められ，乙かもこの内の 6 例に腫瘍の合併が認 められ，さらにその内の 1 例は全身転移を認めたと報
Fig. 9 末梢血リンパ球の subset 比率比較.

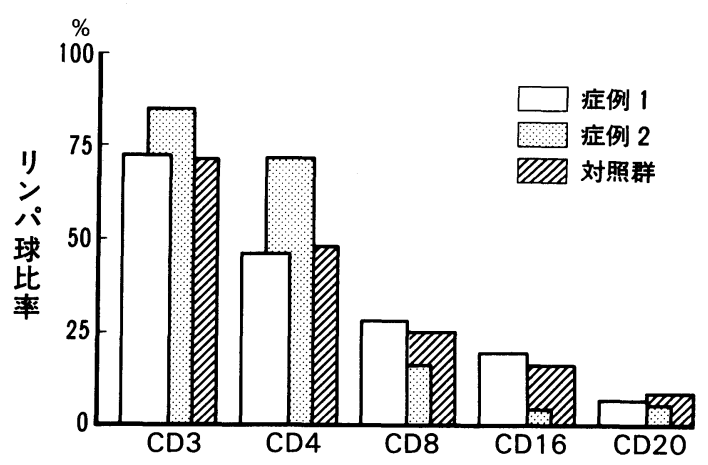

告している.

本邦における透析患者に対する全国的調査 ${ }^{3)}$ を分析 した結果，腎細胞癌の合併発生頻度は，透析人口10万 対年間119例の腎細胞癌の発生が報告されている。これ に対し，一般人の腎細胞癌発生率は，人口 10 万対年間 3 例程度と報告3)されており，それ故，透析患者の腎細 胞癌は一般人に比較して約 40 倍高い発生率になる。 従って, 透析導入以降腎細胞癌の発生する頻度が極め て高いことになり，そのため定期的超音波やCTによ る腎の十分な経過観察が必要となる1778).

この様な臨床的背景にもかかわらず，透析による腎 の囊胞性変化や，囊胞壁にみられる前癌状態，さらに 腎細胞癌の発生の原因はいま持って不明とされてい $~^{3}$. . いくつか考えられている発癌の原因としては大

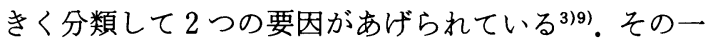
つは発癌物資による発癌である，代表的な発癌物質と しては，尿毒症性代謝物として， nitrogenous waste products， aliphatic amines，それに polyamineなど があげられている339)。 その他，透析機器に含まれる物 質や，消毒薬剤，さらに治療目的で投与された薬剤な ど様々な物質が想定されている尔が，臨床的に実証さ れたものは皆無である。

一方, 透析患者の免疫能の低下が発癌と関連すると する考方方がある ${ }^{9)}$.この点に関して野田ら ${ }^{91}$ は，慢性 腎不全患者の透析導入前から導入後 1 年間にわたる末 梢血の細胞性免疫担当細胞の変動について検討した結 果を報告している。それによると，透析導入直前の慢 性腎不全患者では, 対照正常者に比較して, 末梢血 T リンパ球の幼若化能は低下し, CD3陽性 $\mathrm{T}$ 細胞数, $\mathrm{CD} 4$ 陽性 $\mathrm{T}$ 細胞数, 並びに CD8陽性 $\mathrm{T}$ 細胞数のいず れについても減少し, CD4/CD8比は低下していたと報 告されている99.さらにこれら免疫的パラメーターは 
透析導入後約 2 力月までの比較的短い間にすべて速や かに正常值に近づくが，以後は汪とんど変化せず，透 析導入 1 年後でも正常域には達しなかったと報告され ている ${ }^{9)}$. しかし, 透析患者に発生した腎細胞癌症例の これら免疫的パラメーターに関しての報告は認められ ていない。

最近, 末梢血リンパ球 subset の变動が担癌状態の病 勢を必ずしも反映しないことから ${ }^{10}$, 腫場組織, あるい はそれを取り巻くリンパ節組織を, 免疫組織学的に検 索する手法や11), それらリンパ球の in vitroでの活性 を検索する方法 ${ }^{12)}$ により, 担癌状態の宿主介在性免疫 応答にかかわる細胞の機能を評価する検討が進められ ている。この様な考えから, 今回 ACDK に合併した腎 細胞癌の宿主介在性免疫能を, 一般の腎細胞癌のそれ と比較を試みた。

腫瘍細胞における $\mathrm{MHC}$ 抗原の発現は, 免度監視機 構上最も重要な因子であり, 腫瘍細胞排除の際, CD4陽 性 $\mathrm{T}$ 細胞は class II 抗原を ${ }^{13)}$, CD8陽性 $\mathrm{T}$ 細胞 は class I 抗原を ${ }^{14)}$ それぞれ認識し細胞障害性に作用す る. 今回の検討から症例 1 は, 一般の腎細胞癌に比較 してもこれら MHC 抗原の発現は強く, 従って免疫的 には良好な環境にあることが想像される。しかし, 症 例 2 は, MHC class I 及び class II いずれの抗原も発 現されておらず, 症例 1 とはきわだった差が認められ た。

また $\mathrm{T}$ 細胞受容体の表出は, antigen presenting cell としてのマクロファージに表出されている MHC class II 抗原と結合することにより,腫湟からの抗原を T 細胞が認識する上できわめて重要な役割を果た す ${ }^{15)}$. MHC 拘束性に作用する TCR-alpha/beta chain の表出は ${ }^{16) 17)}$, 症例 1 は一般腎細胞癌と同程度に表出 していたにもかかわらず, 症例 2 ではやはりその表出 が認められなかった。従って, この様な症例では, 腫 瘍抗原を各免疫担当細胞に提示できないことになり, $\mathrm{CD} 4$ 陽性 T 細胞や CD8陽性 $\mathrm{T}$ 細胞などの活性も生じ ないと考兄れる。

腫瘍浸潤リンパ球 (TIL) は, 腫瘍細胞からの抗原を 様々な程度認識した上で, 腫瘍細胞に対し殺細胞性に 働くクローンと帛，逆にこれら免度的正の反応を抑止 するクローン199が混在して存在するとされている。し かし全体としてみれば, TILの浸潤程度と予後の関連 が報告されていることからも ${ }^{20)}$, 宿主介在性免度能が 高い症例に TIL 浸潤が強いと解釈されている。

今回の TIL subset に関する検討から, 症例 1 では,
一般腎細胞癌のそれとほぼ同程度の各 subset 比率を 認めたが, やはり症例 2 では全ての subsetについて浸 潤比率が低く, 腫瘍組織内でのこれら免疫担当細胞の 活性がきわめて低いことが示唆されたことになる。

所属リンパ節リンパ球（RLNL）に関する免度的役 割についてはいまもって不透明であるが，TILに比較 すると腫瘍抗原を認識して活性化されたリンパ球は少 ないとされている21).

今回の検討結果, 症例 1 では CD3陽性 $\mathrm{T}$ 細胞, 特に その内の CD4陽性 $\mathrm{T}$ 細胞が一般腎細胞癌に比較して 浸潤比率が高い結果であったのに比較して, 症例 $2 て ゙$ は, TIL 同様各 subset ともきわめて低く, 従って症例 2 では所属りンパ節においても免疫的に極めて低い状 態と考えられる。同様に, RLNL の TCR も症例 2 で は症例 1 や一般腎細胞癌に比較してその表出率はきわ めて低い結果であった。

従って, 腎不全患者に対する透析に合併した腎細胞 癌 2 症例の宿主介在性免疫能について比較した結果, 少なくとも末梢血リンパ球の免废担当細胞とは大きく 異なる免疫的環境が, 腫瘍組織を中心に認められる症 例が存在することが明らかとなった。 しかも同様の臨 床経過を経て発症した腎細胞癌でも, 症例によりその 免疫環境がきわめて異なることも明らかとなった。さ らに, ACDK に伴う腎細胞癌の発症は症例によりその 免疫環境が発症及び増殖に及ぼす影響が大きく異なる ことが示唆された. 今後さらにこれら症例の予後も含 めた追跡調査が必要であると考えられる。

\section{結 語}

1） 1990 年 6 月より, 1991年 5 月までの 1 年間に慈恵 医大で治療した腎細胞癌の内, 透析患者に合併した後 天性腎囊胞に発症した腎細胞癌 2 症例を経験した。こ れらの症例を対象症例とし, その他の症例14例を比較 対照として, 腫瘍組織を中心とした免疫的環境に関し て検討した。

2) 腫場細胞の MHC 発現では, 対象症例中症例 1 では class I, class II 及び DR 抗原のいずれも，対照 症例に比較して発現率は高かったが, 症例 2 例ではい ずれの MHC 発現も認められなかった。

3）腫場浸潤リンパ球におけるCD25（IL-2 receptor)の表出はいずれの症例も極めて低かったが, $\mathrm{T}$ 細 胞受容体一alpha/beta chain は症例 1 では対象群と ほぼ同程度の表出率であったが, 症例 2 ではやはり表 出されていなかった。ささらに, 腫瘍浸潤リンパ球各 subset については, 症例 1 では各 subset とも対象群と 
同程度の浸潤比率であったが，症例 2 ではいずれの subset についても浸潤比率が低い結果であった。

4）所属リンパ節リンパ球に打けるCD25の表出は 全ての症例に認められなかったが, T細胞受容体 -alpha/beta chain の比率は症例 1 と対照症例間で 差を認めなかったが, 症例 2 では表出されていなかっ た。また、リンパ球各 subset 比率をみると, 症例 1 で は対照症例に比較して CD3陽性 T 細胞の比率が高く, 特にその内 $\mathrm{CD} 4$ 陽性 $\mathrm{T}$ 細胞が高かったのに比較して, 症例 2 では全ての subset 比率が低い結果であった。

5）末梢血リンパ球の検討では, 症例 1 と対照症例間 に各 subset 比率の差はなかったのに比較して, 症例 2 では CD3陽性 $\mathrm{T}$ 細胞の増加と, その内特に $\mathrm{CD} 4$ 陽性 $\mathrm{T}$ 細胞の比率が高かった。

\section{文献}

1）山口 聡, 藤井敬三, 金子茂男, 安済 勉, 稲田文 衛, 小林 武, 吉田桂二, 石田初一：慢性腎不全の 腎超音波診断に関する研究．第 2 編. Acquired cystic disease of the kidneys. 日泌尿会誌, 81, 1183-1189, 1990.

2）宾戸 洋, 二木 源, 鈴木一之, 松原光伸, 鈴木敬 裕, 堀田 修, 黒沢考成, 田熊淑男, 孫 考義, 石 崎 允, 高橋 寿, 岡崎 肇, 関野 宏, 浅木 茂: 持続透析患者によみられた悪性腫瘍症例の検討 (第 2 報)。腎と透析，28，248-252，1990。

3）石川 勲：腎透析患者にみられる腎腫湯発生. Oncologia, 19, 56-69, 1986.

4) Robson, D.J., Churchill, B.M. and Anderson, W.: The results of radical nephrectomy for renal cell carcinoma for renal cell carcinoma. J. Urol., 101, 297-301, 1969.

5) Bannayan, G.A. and Lamm, D.L.: Renal cell tumors. Pathol. Ann., 15, 271-308, 1980.

6) Dunnill, M.S., Millard, P.R. and Oliver, D.: Acquired cystic disease of the kidneys: A hazard of intermittent maintenance haemodialysis. J. Clin. Path., 30, 868-877, 1977.

7) Noronha, I.L., Ritz, E., Waldherr, R., Stein, G. and Fassbinder, W.: Renal cell carcinoma in dialysis patients with acquired renal cysts. Nephrol. Dial. Transplant., 4, 763-769, 1989.

8) Ishikawa, I., Saito, Y., Shikura, N., Kitada, H., Shinoda, A. and Sizuki, S.: Ten-year prospective study on the development of renal cell carcinoma in dialysis patients. Am. J. Kidney Dis., 16, 452-458, 1990.

9）野田春夫, 岡田茂樹, 浜田勝生, 宮崎 重, 澤西謙

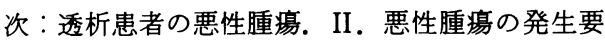
因. 臨床透析, 4, 1579-1584, 1988.
10) Stenzl, A. and deKernion, J.B.: The natural history of renal cell carcinoma. Semin. Urology, 7, 144-148, 1989.

11）大西哲郎：腎細胞癌原発巣浸潤リンパ球 subset の評価と，IFN- $y$ 投与が及ぼす免度的効果に関す る研究。日泌尿会誌，82，216-224，1991.

12）多田富雄：免疫学的試験法. 免疫学イラストレ テッド, 第 2 巻, p. 338-339, 南江堂, 東京, 1990.

13) Rosenthal, A.S. and Shevach, E.M.: Function of macrohages in antigen recognition by guinea pig $\mathrm{T}$ lymphocytes 1 . Requirement for histocompatibile macrophages and lymphocytes. J. Exp. Med., 138, 1194-1212, 1973.

14) Zinkernagel, R.M. and Doherty, P.C.: Restriction of in vitro $\mathrm{T}$ cell-mediated cytotoxicity in lymphocytic choriomeningitis within a syngeneic or semiallo-genic system. Nature, 248, 701-702, 1974.

15) Schwartz, R.H.: T lymphocyte recognition of antigen in association with gene products of the major histocompabibility complex. Ann. Rev. Immunol., 3, 237-250, 1985.

16) Dembic, Z., Hass, W., Weiss, S., McCubrey, J., Kiefer, H., von Boehmer, H. and Steinmetz, M. : Transfer of specificity by murine $\alpha$ and $\beta$ T-cell receptor genes. Nature, 320, 232-238, 1986.

17) Saito, T., Weiss, A., Miller, J., Norcross, M.A. and Germain, R.N.: Specific antigen-Ia activation of transfected human $T$ cells expressing murine Ti $\alpha \beta$-numan $\mathrm{T}_{3}$ receptor complexes. Nature, 325, 125-130, 1987.

18) Zinkernagel, R.M. and Doherty, P.C.: MHCrestricted cytotoxic $T$ cells: Studies on the biological role of polymorphic major transplantation antigens determining $T$-cell restrictionspecificity, function, and responsiveness. Adv. Immunol., 27, 51-177, 1979.

19) Broder, S., Uchiyama, T., Muul, L.M., Goldman, C., Sharrow, S., Poplack, D.P. and Waldmann, T.A.: Activation of leukemic pro-suppressor cells to become suppressor-effector cells. Influence of cooperating normal $\mathrm{T}$ cells. $\mathrm{N}$. Engl. J. Med., 304, 1382-1387, 1981.

20）松田 稔, 長船 男, 古武敏彦, 園田孝夫: 腎細胞 癌, 発育様式およびリンパ球浸潤の臨床的意義に ついて，日泌尿会誌，67，1064-1069，1976.

21) Nakamura, H., Ishiguro, K. and Mori, T.: Different immune functions of peripheral blood, regional lymph node, and tumor infiltrating lymphocytes in lung cancer patients. Cancer, 62, 2489-2497, 1988.

（1991年 8 月 2 日受理） 